\title{
MERGAIČIŲ IDIOPATINĖS SKOLIOZĖS GYDYMAS SCHROTH METODU, NAUDOJANT DIERS 3D DIAGNOSTIKOS SISTEMĄ
}

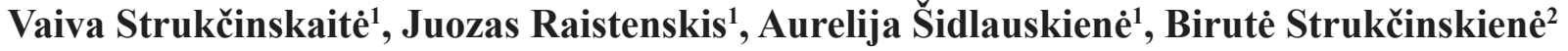 \\ ${ }^{1}$ Vilniaus universiteto Medicinos fakulteto Sveikatos mokslu institutas, \\ ${ }^{2}$ Klaipédos universiteto Sveikatos mokslu fakultetas
}

Raktažodžiai: idiopatinè skoliozè, mergaitès, kineziterapija, Schroth, DIERS 3D.

\begin{abstract}
Santrauka
Vaikų ir paauglių idiopatinė skoliozė yra aktuali ir svarbi jaunų žmonių sveikatos ir gyvenimo kokybès problema. Pastaruoju metu pasaulyje plačiai taikoma mokslo irrodymais pagrista Schroth konservatyvaus skoliozès gydymo metodika, o DIERS 3D diagnostinè sistema yra vienas moderniausių stuburo ir laikysenos diagnostikos metodų. Darbo tikslas buvo įvertinti mergaičių idiopatinès skoliozès gydymo Schroth metodu efektyvumą, taikant diagnostini DIERS 3D tyrimo metodą. Tyrimas atliktas Vilniaus universiteto ligoninès Santaros klinikų (toliau VUL SK) Vaikų ligoninejje, Fizinès medicinos ir reabilitacijos centre. Tyrime dalyvavo $50(n=50)$ 9-17 metų mergaičių, sergančių idiopatine skolioze. Tiriamosios buvo suskirstytos ị dvi grupes: tiriamają $(n=25)$ ir kontrolinę $(n=25)$. Tiriamajai grupei taikyta kineziterapija Schroth gydymo metodu, kontrolinei grupei - iprastinè kineziterapija. Tyrimo metu abiejų grupių pacientėms atlikta 10 kineziterapijos procedūrų. Kineziterapijos efektyvumui vertinti naudotas diagnostinis DIERS 3D tyrimo metodas, skirtas matuoti stuburo ir laikysenos parametrus. Testavimai atlikti prieš ir po reabilitacijos. Statistinei duomenų analizei taikyta SPSS 24.0 programa. Duomenys vertinami kaip statistiškai reikšmingi, kai $\mathrm{p}<0,05$. Analizuojant gydymo efektyvumą DIERS 3D ịrenginiu, nustatyta, kad tiriamojoje grupeje statistiškai reikšmingai padidejo liemens ilgio ịvertis (nuo $403 \mathrm{~mm}$ iki $406 \mathrm{~mm}$ ), sumažèjo liemens disbalanso rodiklis (nuo $2,88 \mathrm{~mm}$ iki $2,04 \mathrm{~mm}$ ), paviršiaus rotacijos laipsnis (nuo $6,04^{0}$ iki $5,32^{\circ}$ ), lateralinès deviacijos ịvertis $(7,84 \mathrm{~mm}$ iki $5,96 \mathrm{~mm})$,

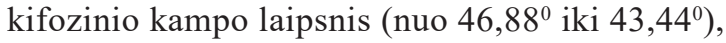

$p<0,05$. Kontrolinèje grupeje statistiškai reikšmingai sumažèjo dubens pakrypimo rodiklis (nuo 4,36 mm iki 3,32 mm). Kontrolinejje grupejje reikšmingai sumažèjo liemens ilgis (nuo $429 \mathrm{~mm}$ iki 422,16 $\mathrm{mm}$ ), rodantis neigiamą pokyti. Dubens pasisukimo parametras turejo tendenciją labiau mažèti tiriamojoje grupejje. Rezultatų pokyčių skirtumų tarp grupių analizè parodè, kad tiriamojoje grupeje lateralinès deviacijos laipsnis statistiškai reikšmingai sumažejjo, lyginant su kontroline grupe. Tai įvyko dèl kontrolinèje grupejje padidejusio šoninio nuokrypio parametro reabilitacijos metu. Tiriamojoje grupejje dauguma parametrų kito statistiškai reikšmingai. Po reabilitacijos statistiškai reikšmingų skirtumų tarp tiriamosios ir kontrolinès grupès nenustatyta.

\section{Ivadas}

Skoliozė yra kompleksinè trimatė stuburo deformacija, kuriai būdingas mažiausiai 10 laipsnių šoninis nuokrypis, susijęs su rotaciniu komponentu. Idiopatinè skoliozė yra labiausiai paplitusi stuburo deformacija, kuri išsivysto kitų patologijų neturintiems vaikams. Paauglių idiopatinè skoliozė dažniausiai pasireiškia vyresniems nei 10 metų vaikams [1]. Paauglių idiopatine skolioze dažniau serga mergaitès, o susirgimų santykis tarp merginų ir vaikinų yra nuo 1,5:1 iki 3:1. Šis santykis ženkliai didejja, didejant paauglių amžiui [2]. Remiantis Tarptautinès skoliozès ortopedinio ir reabilitacinio gydymo asociacijos (toliau - SOSORT) duomenimis, paauglių idiopatinès skoliozès dažnis svyruoja nuo 0,93 iki 12 proc., bet dažniausiai jis siekia 2-3 procentus [3]. Lietuvoje 2008-2018 metų laikotarpiu vaikų ir paauglių skoliozès atvejų procentinè dalis nuo apsilankiusiujjų sveikatos priežiūros įstaigose sumažèjo 0-17, 0-6, 7-14 ir 15-17 metų amžiaus grupèse [4,5]. Nors statistikos rodiklių dešimtmečio tendencijos yra pozityvios, vaikų ir paauglių skoliozès problema tebèra aktuali ir svarbi jaunų žmonių sveikatos ir gyvenimo kokybės problema. 
SOSORT pateikia tokias idiopatinės skoliozės gydymo rekomendacijas [6]: kai stuburo iškrypimo laipsnis yra nuo 10 iki 25 - taikoma specifinè kineziterapija; esant iškrypimui nuo 25 iki 50 laipsnių - rekomenduojamas liemens itvaras-korsetas ir specifine kineziterapija; didesnis nei 50 laipsnių iškrypimas gydomas operaciniu būdu.

Specifinè kineziterapija išsiskiria tuo, kad korekcija, fiziniai pratimai ir padètys skiriami atsižvelgiant $i$ individualų atveji ir stuburo iškrypimo tipą bei laipsnị. Specifinè kineziterapija gydant skoliozę turi aprépti trimatę laikysenos autokorekciją, koreguotą laikysenos stabilizavimą, paciento mokymą ir korekcinių padéčių mokymą kasdieniame gyvenime [7]. Pastaruoju metu pasaulyje plačiai naudojama mokslo įrodymais pagrịsta Schroth konservatyvaus skoliozès gydymo metodika [6]. Schroth metodika - trijų dimensijų skoliozès gydymas. Metodikos esmè - stuburo hiperkorekcija, suprantama kaip tam tikrų pozicijų, priešingų natūralioms kreivėms, pritaikymas ir itvirtinimas specialiais pratimais [8]. Atliekama speciali kineziterapijos procedūra, su akcentu ị korekcines padètis, kurių reikètų laikytis visos paros metu. Tai padeda atkurti stuburo stabilumą ir mobilumą, kuris reikalingas pacientams, sergantiems idiopatine paauglių skolioze su plataus spektro stuburo deformacijomis [9]. Schroth metodo metu reikalingi korekciniai judesiai atliekami statinèje ir dinaminèje padètyse. Šio metodo pratimai užtikrina sensomotorinę ir kinestetinę audinių stimuliaciją, todèl kartu koreguojamas ir patologinis kvépavimo modelis [10]. Schroth metodas buvo sukurtas remiantis biomechanikos ir neurofiziologijos koncepcijomis. Šis metodas leidžia pacientams atgauti normalią laikyseną korekcijos būdu, atliekant stuburo elongaciją, derotaciją, defleksiją, taikant rotacinę kvėpavimo techniką ir stuburo stabilizavimą, esant nepertraukiamam vizualios informacijos grį̌tamajam ryšiui $[10,11,12]$. DIERS 3D diagnostinè sistema yra vienas moderniausių diagnostikos metodų, skirtų stuburo ir laikysenos analizei. Tai diagnostinè paviršinès topografijos sistema, kuria galima analizuoti laikysenos ir stuburo parametrus trijose plokštumose. DIERS 3D diagnostine sistema galima nustatyti liemens ilgị $(\mathrm{mm})$, liemens išlinkimą $\left({ }^{0}\right)$, liemens disbalansą $\left(\mathrm{mm},{ }^{0}\right)$, dubens pakrypimą $\left(\mathrm{mm},{ }^{0}\right)$, dubens pasisukimą $\left({ }^{0}\right)$, kifozinị ir lordozinị kampus $\left(^{0}\right)$, paviršiaus rotaciją $\left(^{0}\right)$, lateralinę deviaciją $\left(\mathrm{mm},{ }^{0}\right)$ [13]. Taikant paauglių idiopatinès skoliozès gydymą Schroth metodu, gali būti naudojama DIERS 3D diagnostikos sistema.

Darbo tikslas - îvertinti mergaičių idiopatinès skoliozès gydymo Schroth metodu efektyvumą, naudojant DIERS 3D diagnostikos sistemą.

\section{Tyrimo medžiaga ir metodai}

Tyrimas atliktas VUL SK Vaikų ligoninejje, Fizinès medicinos ir reabilitacijos centre. Tyrime dalyvavo $50(\mathrm{n}=50)$ 9-17 metų mergaičių, sergančių idiopatine skolioze. Tyrimo dalyvès buvo suskirstytos ị dvi grupes: tiriamają $(n=25)$ ir kontrolinę $(\mathrm{n}=25)$. Tiriamajai grupei taikyta kineziterapija Schroth gydymo metodu, kontrolinei grupei - iprastinè kineziterapija. Tyrimo metu abiejų grupių pacientems atlikta 10 kineziterapijos procedūrų, 5 kartus per savaitę po 30 minučių. Kineziterapijos efektyvumui vertinti naudotas diagnostinis DIERS 3D tyrimo metodas, skirtas matuoti stuburo ir laikysenos parametrus. Testavimai atlikti prieš ir po reabilitacijos. Statistinei duomenų analizei naudotas IBM SPSS 24.0 duomenų analizès paketas ir Microsof Excel programa. Duomenys vertinami kaip statistiškai reikšmingi, kai $\mathrm{p}<0,05$.

\section{Tyrimo rezultatai ir jų aptarimas}

Laikysenos ir stuburo parametrų analizè atlikta taikant DIERS 3D diagnostini tyrimo metodą. DIERS 3D parametrai buvo analizuojami trijose plokštumose - frontalioje, sagitalioje ir horizontalioje.

1 ir 2 lentelèse pateikiami tiriamosios ir kontrolinès grupès idiopatine skolioze sergančių mergaičių DIERS 3D su stuburu ir laikysena susijusių parametrų rezultatai grupių viduje prieš ir po reabilitacijos. Analizuojant tiriamosios grupès mergaičių, kurioms buvo taikytas Schroth gydymo metodas, reabilitacijos efektyvumą, stebimi statistiškai reikšmingi skirtumai tarp prieš ir po reabilitacijos gautu DIERS 3D parametrų. Statistiškai reikšmingai padidejo liemens ilgio įvertis $(\mathrm{p}=0,008)$, sumažejo liemens disbalanso rodiklis $(\mathrm{p}=0,022)$, sumažèjo vidutinis paviršiaus rotacijos laipsnis $(\mathrm{p}=0,006)$, lateralinès deviacijos ịvertis $(\mathrm{p}=0,001), \mathrm{p}<0,05$. Po reabilitacijos statistiškai reikšmingai sumažèjo kifozinio kampo laipsnis, $p=0,021$. Dubens pakrypimo parametrai po reabilitacijos turejo tendenciją mažèti, $p=0,075,(p<0,1)$ (1 lentelè).

Nagrinejjant kontrolinès grupès tiriamųjų DIERS 3D parametrų skirtumus prieš ir po reabilitacijos, stebima kiekybiškai mažiau statistiškai reikšmingų skirtumų, nei tiriamojoje grupejje. Po reabilitacijos statistiškai reikšmingai sumažejo dubens pakrypimo rodiklis, $p=0,005(p<0,05)$. Tiriamujų liemens ilgis po reabilitacijos taip pat statistiškai reikšmingai sumažèjo ir tai rodo neigiamą pokyti, $p=0,001$ $(\mathrm{p}<0,05)$. Po reabilitacijos lordozinis kampas turejjo tendenciją didèti, $\mathrm{p}=0,058(\mathrm{p}<0,1)$ ( 2 lentelè).

Po reabilitacijos eksperimentineje ir kontrolineje grupėse gautų DIERS 3D parametrų rezultatų palyginimas pateikiamas 3 lenteleje. Liemens ilgis tiriamojoje grupeje padidejjo, o kontrolinèje - sumažèjo, tačiau liemens ilgio 
ivertis po reabilitacijos buvo didesnis kontrolinėje grupejje. Liemens disbalansas ir dubens pakrypimas sumažejo abejose grupèse, bet po reabilitacijos mažesnis liemens disbalansas buvo kontrolinejje grupeje. Liemens ilgis, disbalansas ir dubens pakrypimas tarp grupių statistiškai reikšmingai nesiskyrè, $p>0,05$. Dubens pasisukimas po reabilitacijos tiriamojoje grupeje $\left(1,96 \pm 0,79^{\circ}\right)$ buvo $1^{0}$ mažesnis, nei kontrolinëje grupeje $\left(2,96 \pm 2,11^{0}\right)$. Dubens pasisukimo parametro įvertinimas turejo tendenciją labiau mažèti tiriamojoje grupeje, $\mathrm{p}<0,1(\mathrm{p}=0,086)(3$ lentelè).

Su skoliozès diagnoze labiausiai siejamas paviršiaus rotacijos laipsnio parametras, kadangi šis laipsnis koreliuoja su stuburo iškrypimo laipsniu pagal Cobb kampą. Pa-

1 lentelè. Tiriamosios grupès DIERS 3D parametrai ${ }^{*} p<0,05 ; *_{p}^{*}<0,1$

\begin{tabular}{|c|c|c|c|c|c|c|c|c|c|}
\hline \multirow{2}{*}{ DIERS 3D parametrai } & \multicolumn{4}{|c|}{ Prieš reabilitaciją } & \multicolumn{4}{|c|}{ Po reabilitacijos } & \multirow{2}{*}{$\begin{array}{c}\text { p- } \\
\text { reikš- } \\
\text { mé }\end{array}$} \\
\hline & vidurkis & SN & $\min$ & $\max$ & vidurkis & SN & $\min$ & $\max$ & \\
\hline Liemens ilgis $(\mathrm{mm})$ & 402,96 & 35,39 & 321 & 459 & 405,56 & 36,62 & 320 & 462 & 0,008* \\
\hline Liemens disbalansas (mm) & 2,88 & 3,44 & 0 & 15 & 2,04 & 2,48 & 0 & 12 & $0,022 *$ \\
\hline Dubens pakrypimas (mm) & 3,08 & 2,38 & 0 & 6 & 2,48 & 2,71 & 0 & 9 & $0,075 * *$ \\
\hline Dubens pasisukimas $\left({ }^{0}\right)$ & 2,36 & 1,52 & 0 & 5 & 1,96 & 0,79 & 1 & 3 & 0,179 \\
\hline Paviršiaus rotacija - rms $\left({ }^{0}\right)$ & 6,04 & 2,46 & 1 & 11 & 5,32 & 2,34 & 1 & 9 & $0,006 *$ \\
\hline Lateralinè deviacija $(\mathrm{mm})$ & 7,84 & 4,56 & 1 & 20 & 5,96 & 4,02 & 0 & 16 & 0,001* \\
\hline Kifozinis kampas $\left({ }^{0}\right)$ & 46,88 & 13,73 & 12 & 71 & 43,44 & 13,06 & 13 & 68 & 0,021* \\
\hline Lordozinis kampas $\left({ }^{0}\right)$ & 46,60 & 10,51 & 29 & 65 & 46,64 & 9,83 & 27 & 63 & 0,431 \\
\hline
\end{tabular}

2 lentelè. Kontrolinès grupès DIERS 3D parametrai ${ }^{*} p<0,05 ; *^{*} p<0,1$

\begin{tabular}{|c|c|c|c|c|c|c|c|c|c|}
\hline \multirow{2}{*}{ DIERS 3D parametrai } & \multicolumn{4}{|c|}{ Prieš reabilitaciją } & \multicolumn{4}{|c|}{ Po reabilitacijos } & \multirow{2}{*}{$\begin{array}{c}\text { p- } \\
\text { reikšmė }\end{array}$} \\
\hline & vidurkis & SN & $\min$ & $\max$ & vidurkis & SN & $\min$ & $\max$ & \\
\hline Liemens ilgis (mm) & 429 & 32,07 & 338 & 474 & 422,16 & 31,58 & 344 & 475 & $0,001 *$ \\
\hline Liemens disbalansas (mm) & 1,80 & 2,14 & 0 & 11 & 1,44 & 1,00 & 0 & 4 & 0,593 \\
\hline Dubens pakrypimas (mm) & 4,36 & 3,53 & 0 & 12 & 3,32 & 3,08 & 0 & 11 & $0,005 *$ \\
\hline Dubens pasisukimas $\left({ }^{0}\right)$ & 2,80 & 2,16 & 0 & 10 & 2,96 & 2,11 & 0 & 9 & 0,569 \\
\hline Paviršiaus rotacija - rms $\left({ }^{0}\right)$ & 5,64 & 2,77 & 2 & 13 & 5,48 & 3,45 & 1 & 13 & 0,328 \\
\hline Lateralinė deviacija (mm) & 6,80 & 3,30 & 0 & 13 & 10,12 & 13,76 & 0 & 55 & 0,876 \\
\hline Kifozinis kampas $\left({ }^{0}\right)$ & 44,80 & 9,15 & 28 & 62 & 45,64 & 7,15 & 33 & 60 & 0,147 \\
\hline Lordozinis kampas $\left({ }^{0}\right)$ & 42,56 & 12,23 & 19 & 65 & 43,96 & 10,12 & 21 & 65 & $0,058 * *$ \\
\hline
\end{tabular}

3 lentelè. Tiriamųų DIERS 3D parametrų rezultatai po reabilitacijos

\begin{tabular}{|c|c|c|c|c|c|c|c|c|c|}
\hline \multirow{2}{*}{ DIERS 3D parametrai } & \multicolumn{4}{|c|}{ Tiriamoji grupé } & \multicolumn{4}{|c|}{ Kontrolinė grupė } & \multirow{2}{*}{$\begin{array}{c}\text { p- } \\
\text { reikšme }\end{array}$} \\
\hline & vidurkis & SN & $\min$ & $\max$ & vidurkis & SN & $\min$ & $\max$ & \\
\hline Liemens ilgis $(\mathrm{mm})$ & 405,56 & 36,62 & 320 & 462 & 422,16 & 31,58 & 344 & 475 & 0,123 \\
\hline Liemens disbalansas (mm) & 2,04 & 2,48 & 0 & 12 & 1,44 & 1,00 & 0 & 4 & 0,556 \\
\hline Dubens pakrypimas (mm) & 2,48 & 2,71 & 0 & 9 & 3,32 & 3,08 & 0 & 11 & 0,366 \\
\hline Dubens pasisukimas $\left({ }^{0}\right)$ & 1,96 & 0,79 & 1 & 3 & 2,96 & 2,11 & 0 & 9 & 0,086 \\
\hline Paviršiaus rotacija - rms $\left({ }^{0}\right)$ & 5,32 & 2,34 & 1 & 9 & 5,48 & 3,45 & 1 & 13 & 0,799 \\
\hline Lateraliné deviacija (mm) & 5,96 & 4,02 & 0 & 16 & 10,12 & 13,76 & 0 & 55 & 0,274 \\
\hline Kifozinis kampas $\left({ }^{0}\right)$ & 43,44 & 13,06 & 13 & 68 & 45,64 & 7,15 & 33 & 60 & 0,528 \\
\hline Lordozinis kampas $\left({ }^{0}\right)$ & 46,64 & 9,83 & 27 & 63 & 43,96 & 10,12 & 21 & 65 & 0,443 \\
\hline
\end{tabular}

viršiaus rotacijos rezultatai po reabilitacijos grupèse buvo panašūs. 1 paveiksle stebimi paviršiaus rotacijos laipsnio ìverčiai prieš $\left(6,04 \pm 5,32^{\circ}\right.$ ir $5,64 \pm 2,77^{\circ}$ ) ir po reabilitacijos $\left(5,32 \pm 2,34^{0}\right.$ ir $\left.5,48 \pm 3,45^{\circ}\right)$ tarp tiriamosios ir kontrolinès grupių. Po reabilitacijos tiek tiriamosios, tiek kontrolinès grupès tiriamujų vidutinès paviršiaus rotacijos vertès statistiškai reikšmingai nesiskyrè ( $\mathrm{p}>0,05)$.

3 lenteleje stebint lateralinès deviacijos rezultatus po reabilitacijos tarp grupių, apskaičiuotas 4,16 $\mathrm{mm}$ skirtumas. Tiriamojoje grupejje lateralinès deviacijos rezultatas $(5,96 \pm 4,02$ $\mathrm{mm}$ ) beveik dvigubai mažesnis, nei kontrolinèje grupejje $(10,12 \pm 13,76$ $\mathrm{mm})$, tačiau statistiškai reikšmingo skirtumo nenustatyta $(\mathrm{p}=0,274)$. Kifozinio, kaip ir lordozinio kampo rezultatai po reabilitacijos tarp grupių statistiškai reišmingai nesiskyrè. Nei tiriamojoje, nei kontrolinėje grupejje kifozinio ir lordozinio kampo rezultatai po reabilitacijos neatitiko DIERS 3D intrukcijose aprašytų natūralių stuburo fiziologinių linkių normų. Tiriamojoje grupeje šių ịverčiu rezultatai buvo artimesni normoms, nei kontrolinejje.

4 lentelèje stebimi reabilitacijos metu DIERS 3D diagnostine sistema gautų parametrų rezultatų pokyčiai. Liemens ilgis tiriamojoje grupeje viduti- 
niškai didejjo 1,64 mm. Liemens ilgio vidutinis pokytis kontrolinèje grupeje $1,44 \mathrm{~mm}$ didesnis nei tiriamojoje, tačiau po reabilitacijos kontrolinès grupès liemens ilgis buvo mažesnis, negu prieš reabilitaciją. Liemens disbalanso i šoną vidutinis pokytis tiriamojoje grupeje $(-0,80 \mathrm{~mm})$ buvo statistiškai reikšmingai beveik dvigubai didesnis, nei kontrolineje grupeje $(-0,44 \mathrm{~mm}), \mathrm{p}=0,048$. Dubens pakrypimo rezultato pokytis tiriamojoje grupeje buvo $-0,52 \mathrm{~mm}$, kontrolinèje grupeje šis pokytis buvo $-1,12 \mathrm{~mm}$. Dubens pakrypimo vidutinis pokytis $(\mathrm{mm})$, kaip ir dubens pasisukimo pokytis $\left({ }^{0}\right)$, statistiškai reikšmingai nesiskyré tarp tiriamosios ir kontrolinès grupès tiriamujų, $(p=0,900$ ir $p=0,203)$. Paviršiaus rotacijos laipsnio vidutinis pokytis tiriamojoje grupejje buvo $-0,72^{\circ}$, o kontrolinèje grupejje vidutinis pokytis buvo $0,56^{\circ}$ mažesnis, nei tiriamojoje $\left(-0,16^{0}\right)$, tačiau statistiškai reikšmingo skirtumo nebuvo. 2 paveiksle galime stebèti, kaip kito tiriamosios ir kontrolinès grupès individualių tiriamujjų paviršiaus rotacijos laipsnis. Tiriamojoje grupeje stebimas didesnis tiriamujų, kuriems po kineziterapijos sumažèjo paviršiaus rotacijos parametras, skaičius nei kontrolinèje grupejje (2 pav.).

4 lentelèje stebint vidutinị lateralinès deviacijos pokytị, tarp grupių pastebèti statistiškai reikšmingi skirtumai, $p=0,049$. Lateralinè deviacija tiriamojoje grupejje vidutiniškai mažèjo $1,28 \mathrm{~mm}$, o kontrolinėje grupejje vidutiniškai didejo 2,76 mm. Analizuojant kifozinio ir lordozinio kampo vidutinių pokyčių skirtumus tarp grupių, statistiškai reikšmingų skirtumų nepastebèta, $p>0,05$. Kifozinis kampas vidutiniškai mažèjo abiejose grupèse, o lordozinis kampas - tik kontrolinėje grupejje (4 lentelè).

Analizuojant dubens pakrypimą pagal DIERS 3D intrukcijose pateikiamas parametrų įverčių ribas, prieš reabilitaciją skoliozinei laikysenai būdingus $(<4 \mathrm{~mm})$ ịverčius turèjo 65 proc. tiriamosios grupès ir 60 kontrolinès grupès tiriamụjų, o skoliozei būdingus ịverčius - 32 proc. ir 40 proc. tiriamujų. Tiriamojoje grupeje po reabilitacijos 3 proc. mažiau tiriamujų turejjo skoliozei būdingų įverčių. Kontrolinès grupès pasiskirstymas po reabilitacijos nekito (3a pav.).

Analizuojant dubens pasisukimą pagal
DIERS 3D ịrenginio kūrejjų aprašytas normas, nustatyta, kad prieš reabilitaciją $<2^{0}$ dubens pasisukimą turejjo 60 proc. tiriamosios ir 56 proc. kontrolinès grupès atstovių, o $>2^{0}$ dubens pasisukimą -40 proc. ir 44 proc. tiriamujų. Po reabilitacijos keitèsi tik tiriamosios grupès pasiskirstymas - skoliozinei laikysenai būdingą dubens pasisukimą turejjo 72 proc., o skoliozei - 28 proc. tiriamujų ( $3 \mathrm{~b}$ pav.).

Pagal DIERS 3D instrukcijose pateiktas normas, liemens disbalansas $>5 \mathrm{~mm}$ rodo skoliozinę netaisyklingą laikyseną, liemens disbalansas $>5$ $\mathrm{mm}$ būdingas skolioziniam stuburui. Po reabilitacijos $<5 \mathrm{~mm}$ liemens disbalansą turejjo 96 proc. tiriamosios ir kontrolinès grupès dalyvių. Pagal normas liemens disbalansas neturi viršyti 7,5 mm. Prieš reabilitaciją šių

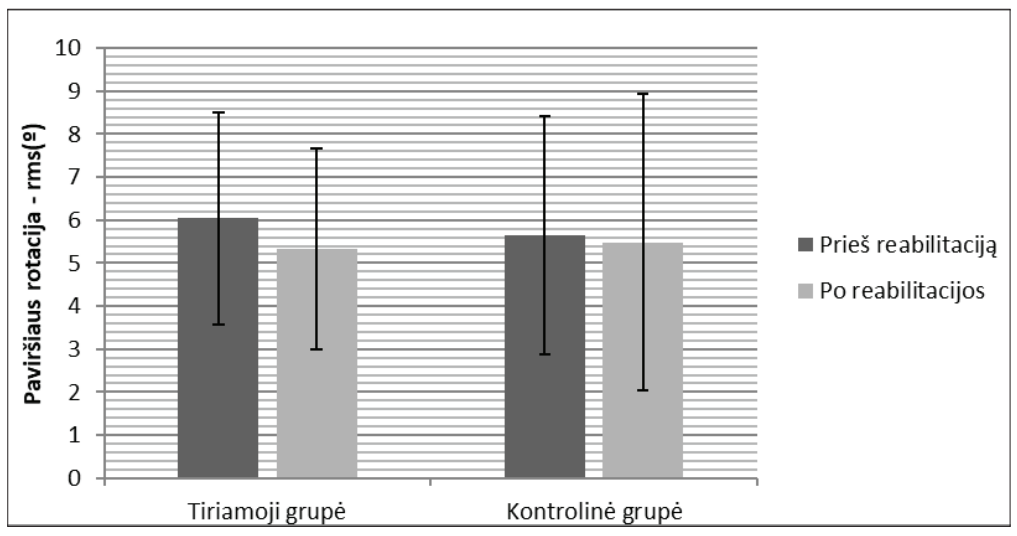

1 pav. Paviršiaus rotacija tarp grupių prieš ir po reabilitacijos
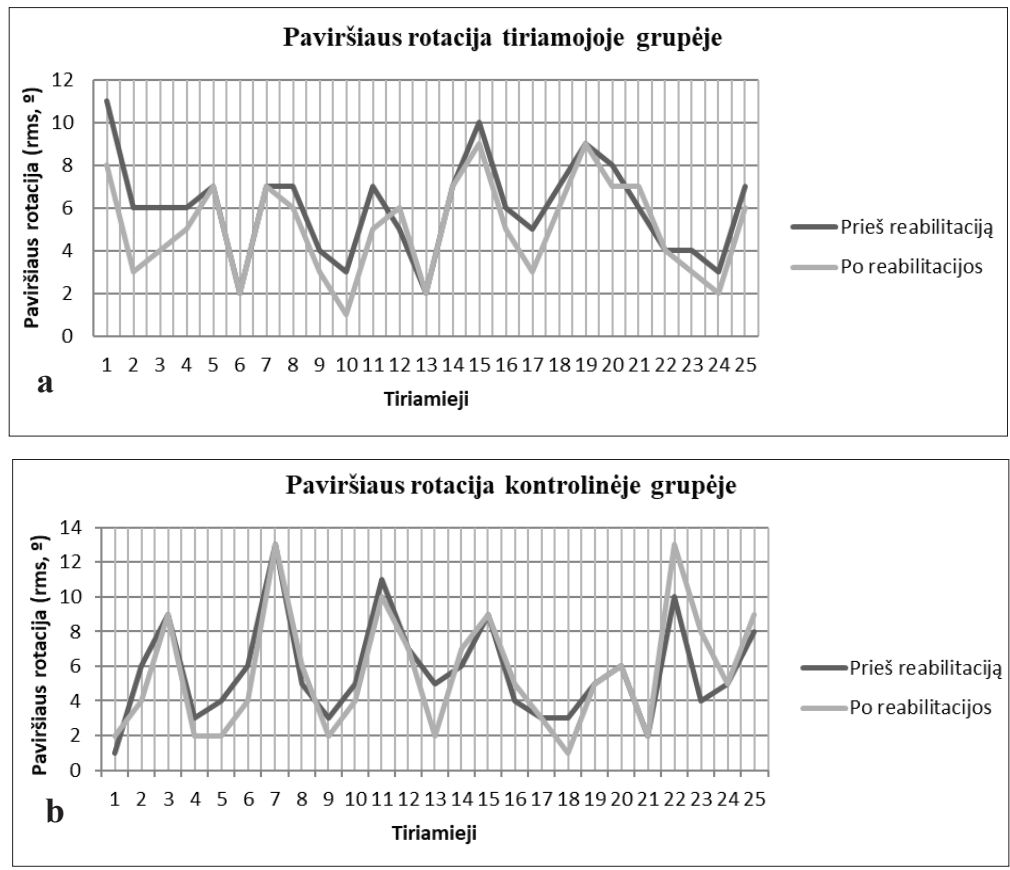

2 pav. Paviršiaus rotacijos laipsnio kitimas tiriamojoje (a) ir kontrolinėje (b) grupèse 
4 lentelè. DIERS 3D parametrų vidutiniški pokyčiai tarp grupių ${ }^{*} p<0,05$

\begin{tabular}{|c|c|c|c|}
\hline Parametras & $\begin{array}{c}\text { Tiriamoji } \\
\text { grupé, } \\
\text { pokytis }\end{array}$ & $\begin{array}{l}\text { Kon- } \\
\text { trolinė } \\
\text { grupé, } \\
\text { pokytis }\end{array}$ & $\stackrel{\text { p- }}{\text { reikšmé }}$ \\
\hline Liemens ilgis (mm) & 1,64 & 3,08 & 0,678 \\
\hline Liemens disbalansas ị šoną $(\mathrm{mm})$ & $-0,80$ & $-0,44$ & 0,048 \\
\hline Dubens pakrypimas $(\mathrm{mm})$ & $-0,52$ & $-1,12$ & 0,900 \\
\hline Dubens pasisukimas $\left({ }^{0}\right)$ & $-0,40$ & 0,16 & 0,203 \\
\hline Paviršiaus rotacija - rms $\left({ }^{0}\right)$ & $-0,72$ & $-0,16$ & 0,169 \\
\hline Lateralinė deviacija $(\mathrm{mm})$ & $-1,28$ & 2,76 & 0,049* \\
\hline Kifozinis kampas $\left({ }^{0}\right)$ & $-2,56$ & $-0,20$ & 0,066 \\
\hline Lordozinis kampas $\left({ }^{0}\right)$ & 1,68 & $-0,48$ & 0,508 \\
\hline
\end{tabular}
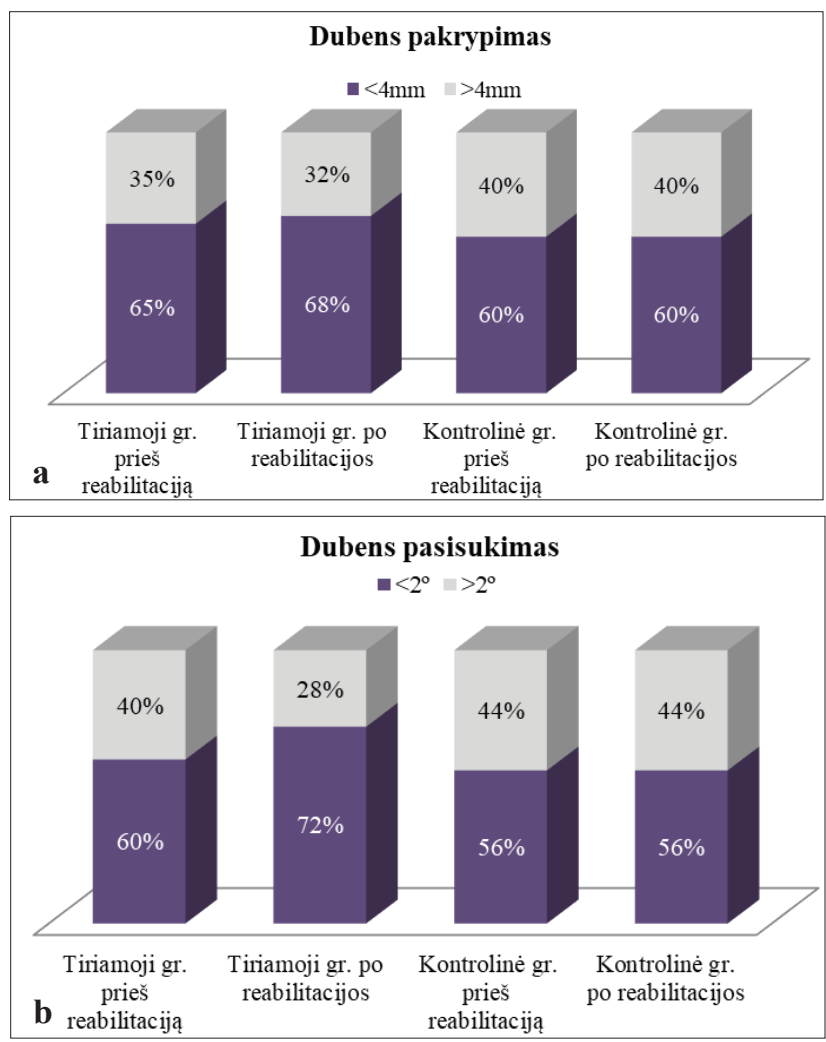

3 pav. Dubens pakrypimas (a) ir dubens pasisukimas (b) pagal DIERS 3D normas

normų neviršijo 96 proc. tiriamosios ir 92 proc. kontrolinès grupès mergaičių. Po reabilitacijos liemens disbalanso normas atitiko visos mergaitès tiriamojoje grupeje ir 96 proc. kontrolinèje grupéje.

DIERS 3D rezultatu interpretacijose skoliozinei laikysenai būdingas $<5^{0}$ paviršiaus rotacijos laipsnis, o skolioziniam stuburui $>5^{0}$ paviršiaus rotacijos laipsnis. Prieš reabilitaciją $<5^{0}$ paviršiaus rotacijos laipsni turèjo 24 proc. tiriamosios ir 40 proc. kontrolinès grupès, po reabilitacijos - 36 proc. ir 48 proc. tirtų mergaičių. Skoliozei būdingą $>5^{0}$ paviršiaus rotacijos laipsni prieš reabilitaciją turèjo 76 proc., po reabilitacijos -64 proc. tiriamosios grupès mergaičių. Kontrolineje grupeje $>5^{0}$ paviršiaus rotacijos laipsni prieš reabilitaciją turejo 60 proc., po reabilitacijos -52 proc. tiriamujų. Nagrinèjant, kiek procentų tiriamujų paviršiaus rotacijos laipsnis kito $\geq 2^{0}$, nustatyta, kad po 24 proc. tiriamujų kiekvienoje grupeje.

Lietuvoje ir kitose šalyse dalis specialistu mano, kad idiopatine skolioze sergančio asmens stuburo nepakoreguosi, taikydamas konservatyvias technikas. M. Rigo ir kt. rekomenduoja paaugliams, sergantiems idiopatine skolioze, taikyti specialius konservatyvaus gydymo metodus, nes tai gali statistiškai reikšmingai sumažinti chirurginio gydymo poreiki [14]. 2014 m. pasiekta statistiškai reikšmingų Schroth ir SEAS metodikų rezultatų vyresnio amžiaus pacientei $(64 \mathrm{~m}$.), kurios skoliozè per trejus metus progresavo 20 laipsnių. Paciente penkių mènesių laikotarpiu 10 valandų buvo konsultuojama specialisto ir kiekvieną dieną 20 min. aktyviai atlikdavo jai paskirtus pratimus. Po metų skoliometru matuota slankstelių rotacija sumažejo nuo $8^{0}$ iki $4^{0}$, Cobb kampas sumažèjo nuo $35^{\circ}$ iki $25^{\circ}$, DIERS diagnostiniu tyrimo metodu nustatyta, kad sumažèjo kūno disbalansas, padidejo liemens ilgis, juosmeninès lordozès laipsnis, sumažèjo paviršiaus rotacijos laipsnis. Pacientė buvo tikslineje chirurginio gydymo grupeje, bet po vienų konservatyvaus gydymo metu, jos būklè ženkliai pagerèjo [15]. Tie patys autoriai analizavo specialiosios kineziterapijos efektyvumą taikant Schroth gydymo metodą $12 \mathrm{~m}$. mergaitei, esant didžiausiai ligos progresavimo rizikai. Po 16 gydymo mènesių buvo pasiekti panašūs pozityvūs rezultatai [16], parodę, kad teigiamų statistiškai reikšmingų specialiosios kineziterapijos taikant Schroth metodą rezultatų galima pasiekti dirbant su sunkiais ir aukštą progresijos riziką turinčiais pacientais.

Apibendrinant galima teigti, kad norint pasiekti efektyvaus gydymo rezultatų, reikètų taikyti intensyvias Schroth gydymo procedūras, kurių trukmè būtų 1 valanda bent 6 savaites, penkias dienas per savaitę. Lietuvoje reiketų populiarinti specialiają kineziterapiją, siekiant, kad kuo daugiau žmonių apie ją žinotų ir imtųsi konservatyvių skoliozès valdymo metodų. Taip būtų galima sumažinti chirurginio gydymo dažnị skolioze sergantiems vaikams.

Pacientams, sergantiems idiopatine skolioze, rekomenduojama skirti daugiau reabilitacijos-kineziterapijos procedūrų. Šios procedūros turètų būti intensyvesnès ir trukti ilgesni laiką. Pacientams, sergantiems skolioze, patariama būti fiziškai aktyviems. Renkantis fizinio aktyvumo tipą, 
reikètų atkreipti dėmesị $i$ tai, kad fizinė veikla nepakenktų stuburo asimetrijai. Be to, pacientams, sergantiems skolioze, rekomenduojama nuolat kontroliuoti savo laikyseną, kūno padèti bei stengtis taisyklingai kvẻpuoti.

\section{Išvados}

Dubens pasisukimo parametro ịvertinimas turèjo tendenciją labiau mažèti tiriamojoje grupeje. Analizuojant rezultatų pokyčių skirtumus tarp grupių stebima, kad tiriamojoje grupèje lateralinès deviacijos laipsnis statistiškai reikšmingai sumažějo, lyginant su kontroline grupe. Tai ìvyko dèl kontrolinèje grupejje padidejjusio šoninio nuokrypio parametro reabilitacijos metu. Tiriamojoje grupeje dauguma parametrų kito statistiškai reikšmingai. Po reabilitacijos statistiškai reikšmingų skirtumų tarp tiriamosios ir kontrolinès grupès nenustatyta.

\section{Literatūra}

1. Choudhry MN, Ahmad Z, Verma R. Adolescent idiopathic scoliosis. The Open Orthopaedics Journal 2016;10:143-154. https://doi.org/10.2174/1874325001610010143

2. Konieczny MR, Senyurt H, Krauspe R. Epidemiology of adolescent idiopathic scoliosis. Journal of Children's Orthopaedics 2013;7(1):3-9.

https://doi.org/10.1007/s11832-012-0457-4

3. Negrini S, Aulisa AG, Aulisa L, Circo A B, Mauroy JC, Durmala J, et al. 2011 SOSORT guidelines: orthopaedic and rehabilitation treatment of idiopathic scoliosis during growth. Scoliosis 2012;7(1):3.

https://doi.org/10.1186/1748-7161-7-3

4. Lietuvos gyventojų sveikata ir sveikatos priežiūros įstaigų veikla 2008. Vilnius, Sveikatos informacijos centras, 2009.

5. Lietuvos gyventojų sveikata ir sveikatos priežiūros įstaigų veikla 2018. Vilnius, Sveikatos informacijos centras, 2019.

6. Negrini S, Hresko TM, O'Brien JP, Price N, SOSORT Boards, SRS non-operative committee. Recommendations for research studies on treatment of idiopathic scoliosis: consensus 2014 between SOSORT and SRS non-operative management committee. Scoliosis 2015;10:8.

https://doi.org/10.1186/s13013-014-0025-4

7. Weiss HR. Schroth therapy: advancements in conservative scoliosis treatment. Saarbruecken: LAP Lambert Academic Publishing 2015.

8. Fusco C, Zaina F, Atanasio S, Romano M, Negrini A, Negrini S. Physical exercises in the treatment of adolescent idiopathic scoliosis: an updated systematic review. Physiotherapy Theory and Practice 2011;27(1):80-114.

https://doi.org/10.3109/09593985.2010.533342

9. Kuru T, Yeldan İ, Dereli EE, Özdinçler AR, Dikici F, Çolak İ. The efficacy of three-dimensional Schroth exercises in adolescent idiopathic scoliosis: a randomised controlled clinical trial.
Clinical Rehabilitation 2016;30:181-190.

https://doi.org/10.1177/0269215515575745

10. Weiss H.R. The method of Katharina Schroth - history, principles and current development. Scoliosis 2011;6:17.

https://doi.org/10.1186/1748-7161-6-17

11. Otman S, Kose N, Yakut Y. The efficacy of Schroth's 3-dimensional exercise therapy in the treatment of adolescent idiopathic scoliosis in Turkey. Saudi Medical Journal 2005;26: 1429-1435.

12. Schreiber S, Parent EC, Hedden DM, Moreau M, Hill D, Lou E. Effect of Schroth exercises on curve characteristics and clinical outcomes in adolescent idiopathic scoliosis: protocol for a multicentre randomised controlled trial. Journal of Physiotherapy 2014;60(4):234.

https://doi.org/10.1016/j.jphys.2014.08.005

13. Frerich JM, Hertzler K, Knott P, Mardjetko S. Comparison of radiographic and surface topography measurements in adolescents with scoliosis. The Open Orthopaedic Journal, 2012;6:261-265.

https://doi.org/10.2174/1874325001206010261

14. Rigo M, Reiter CH, Weiss HR. Effect of conservative management on the prevalence of surgery in patients with adolescent idiopathic scoliosis. Pediatric Rehabilitation 2003;6(3-4):209214.

https://doi.org/10.1080/13638490310001642054

15. Gogin M, Arndt P, Marti C. Effects of scoliosis specific exercise on a $64 \mathrm{y} \%$ woman with degenerative scoliosis. Scoliosis 2014;9(1):O49.

https://doi.org/10.1186/1748-7161-9-S1-O49

16. Gogin M, Arndt P, Marti C. Effects of scoliosis specific conservative management of an adolescent female with is with high risk of progression. Scoliosis 2014;9(1):6.

https://doi.org/10.1186/1748-7161-9-S1-P6

\section{TREATMENT OF IDIOPATHIC SCOLIOSIS IN GIRLS BY SCHROTH METHOD USING DIAGNOSTIC DIERS 3D DEVICE}

\section{Strukčinskaitė, J. Raistenskis, A. Šidlauskienė,} B. Strukčinskienė

Keywords: idiopathic scoliosis, girls, physiotherapy, Schroth method, DIERS 3D.

\section{Summary}

The idiopathic scoliosis problem in children and adolescents remains a pressing and important issue for young people's health and quality of life. Recently, scientifically based Schroth conservative scoliosis treatment method is widely used in the world, and DIERS 3D diagnostic system is one of the most advanced diagnostic methods for spine and posture analysis.

The aim of the study was to evaluate Schroth method effectiveness on posture and spine parameters using DIERS 3D diagnostic test method. The study was conducted at the Physical Medicine and Rehabilitation Centre, Children's Hospital, VUH Santaros clinics. In the study participated 50 girls aged 9-17 years 
with idiopathic scoliosis. The patients were divided into two groups: the study group $(n=25)$ and the control group $(n=25)$. Schroth treatment method for the study group and a traditional physiotherapy for the control group were used. For patients were applied 10 procedures of physiotherapy (for 30 minutes, 5 times a week).

The study showed that analyzing the effectiveness of treatment with DIERS 3D device, in the experimental group the estimate of trunk length significantly increased (from $403 \mathrm{~mm}$ to 406 $\mathrm{mm}$ ). The assessment indicator for trunk imbalance (from $2.88 \mathrm{~mm}$ to $2.04 \mathrm{~mm}$ ), the surface of rotation degree (from $6.04^{\circ}$ to $5.32^{\circ}$ ), lateral deviation $(7.84 \mathrm{~mm}$ to $5.96 \mathrm{~mm}$ ), and kyphotic angle degree (from $46.88^{\circ}$ to $43.44^{\circ}$ ) significantly decreased $(p<0.05)$. In the control group, significant decrease in pelvic torsion parameter (from $4.36 \mathrm{~mm}$ to $3.32 \mathrm{~mm}$ ) was observed; a significant decrease in trunk length (from $429 \mathrm{~mm}$ to $422.16 \mathrm{~mm}$ ), was revealed, indicating a negative change.
Evaluation of pelvic rotation parameter tended to decrease more in the study group. Analyzing differences in outcomes between groups, the degree of lateral deviation was significantly reduced in the study group compared to the control group. This was due to an increase in the lateral deviation parameter in the control group during the physiotherapy. Most parameters changed statistically significantly in the study group. However, after rehabilitation, no statistically significant differences were found between the study and control groups.

Correspondence to: vaiva.struk@gmail.com

Gauta 2020-01-23 